DOI https://doi.org/10.18551/rjoas.2017-10.29

\title{
MARKETING DYNAMICS MODEL OF HIGHLAND VEGETABLE COMMODITIES IN EFFORTS TO INCREASE FARMERS' INCOME
}

\author{
Darmawan Dwi Putra*, Arisena Gede Mekse Korri, Utami Ni Wayan Febriana \\ Faculty of Agriculture, Udayana University, Bali, Indonesia \\ Baskara I Gde Kajeng \\ Faculty of Economics and Business, Udayana University, Bali, Indonesia \\ *E-mail: dwiputradarmawan@yahoo.com
}

\begin{abstract}
Most of the highland vegetable farming sites are located in areas with mountain topography, transportation and limited economic resources. There is a considerable spatial distance between the location of the farm and the consumer, causing a growing complexity of marketing problems and the growing number of marketing institutions that participate in the created marketing channels. Farmers' efforts to increase vegetable production will not be useful if the marketing aspect is not taken seriously. Marketing is part of a vulnerable point in the agribusiness system, because the marketing problem is closely related to the farmers price level. The method used for this research is a stepwise method that ultimately is used to create the model. The final result in this research is the dynamics model of highland marketing vegetable commodities.
\end{abstract}

\section{KEY WORDS}

Dynamics model, marketing institution, marketing communication, farmer's welfare.

Most of the highland vegetable farming sites are located in areas with mountain topographic forms where transportation and economic resources are generally limited. Besides, the size of highland vegetable farming is generally small and the quality is not standard yet, thus causing the marketing process to provide opportunities for the emergence of intermediaries or marketing agencies that carry out marketing functions.

The spatially distant spacing between the location of the farm (Bedugul highland) and the consumer (Denpasar City) caused the complexity of marketing problems and the growing number of marketing institutions that participate in the marketing channels created. The growing number of marketing agencies involved in the vegetable marketing channel can lead to informal cooperation relationships between intermediary traders and farmers.

Vegetable farmers tend to choose traditional marketing channels through middleman, although they receive a smaller share of prices compared to formal channels. This institutional option is often associated with strong ties between vegetable traders and historically-formed farmers with emphasis on familial elements. Inequality in the mastery of science and technology, land, capital, and market access among agribusiness actors led to institutional structures of business partnerships on fragile vegetable commodities.

Farmers as producers do not have the power to determine the selling price in accordance with the quality, thus they are in a weak position at the time of pricing. This happens because of an imbalance between productivity and marketing. Farmers' efforts to increase vegetable production will not be useful if the marketing aspect is not taken seriously. Marketing is part of a vulnerable point in the agribusiness system, because the marketing problem is closely related to the price level received by farmers.

\section{METHODS OF RESEARCH}

The research's population were all vegetable farmers who work on the agricultural sector of horticulture in Buleleng Regency. The number of samples are 50 farmers. Roscoe 
(1975) who gave a statement in a book by Sekaran (2006) about the general reference for determining sample sizes over 30 and less than 500 is appropriate for most studies. Data collection is conducted in Sukasada sub-district by using accidental sampling method. In addition, beside the farmers, vegetable marketing institutions also involved, using snowballs sampling. In this case the initial sample is farmers and the other sample is the marketing agency selected by the sample farmers.

The analysis is conducted gradually on the data that has been obtained. In this research, there are six stages, so in the end there is a model of marketing dynamics of highland vegetable commodity marketing. Stages of analysis in more detail can be explained as follows.

The first stage is spatial analysis in the form of mapping of highland vegetable farming area. The mapping use the image map sourced from Google Earth and land cover in the form of vegetable garden done with ground truth check in the field. Then will be generated map of vegetable commodity distribution which is in region Buleleng Regency. The second stage is to analyze the factors that affect farmers in marketing highland vegetable commodities. The second objective is analyzed by the analysis of frequency tabulation and cross tabulation, through the scoring of qualitative descriptions from respondents in-depth interviews.

The third stage analyzes farmer's communication network in marketing highland vegetable commodity in Buleleng Regency. The fourth stage analyzes the institutional economy of highland vegetable commodities in Buleleng Regency. The fourth objective is analyzed by using qualitative descriptive institutional analysis. Institutional analysis is focused on patterns, rules of the game and interaction patterns between partner institutions. The fifth stage analyzes the marketing channels of highland vegetable commodities in Buleleng Regency. The sixth stage is to build a model of marketing dynamics of highland vegetable commodities. The six objectives were analyzed descriptively qualitative based on the results of first, second, third, fourth and fifth stage analysis.

\section{RESULTS AND DISCUSSION}

Most of the highland vegetable farmers in Buleleng Regency market the vegetable products to the collecting traders. Marketing to the collecting traders is due to the low cost of transportation to transport the trade from farmers to traders. Farmers charge marketing fees to the collecting traders, because they pick up the farmers' harvests. The collecting traders in the payment system use the cash payment system, while the suppliers pay in installments. In the case of payment systems farmers expect a response from buyers to immediately provide some money as a means of exchanging the vegetables they produce. The low cost of transportation for farmers was due to the sale and purchase transactions conducted in the garden or in the farmer's house.

Farmers market vegetables developed only to collecting traders and suppliers, then in the pricing system can be seen which party is dominant (price determinant) and the recipient price. In the marketing system of vegetables, farmers prefer to market their products through the means of mobile phone communication, because farmers want to release the social ties that occur with traders who make transactions directly. In other words, farmers prefer communication patterns in transacting with traders, where social status does not play as an important role.

The communication network of vegetable marketing is important to describe. This is because the marketing of vegetables is very diverse. One way to understand the communication network of highland vegetable marketing is to observe the social relations that occur as a result of interpersonal communication process. Interaction certainly begins with contacts that lead to the tendency to share information with other individuals and the realization of interaction will lead to whom it relates to whom. Farmers will establish a communication network in sharing information about vegetable marketing.

Farmers sold their vegetables to collecting traders, middlemen and some who sold directly to consumers. Occurs the spread of information flow on all individual vegetable 
farmers in a marketing system. Sometimes farmers' communications with one another are not connected, this illustrates that the level of individuality of vegetable farmers selling vegetables is still very high.Vegetable sales are still dominated by the presence of collecting traders or middlemen.

Farmers as individuals certainly have differences between each other in terms of involvement in communication networks. Internal and external factors are associated with communication networks consisting of degrees of connectedness, degree of integration and degree of openness. This means the younger the farmers then the participation in communication networks tend to be higher.

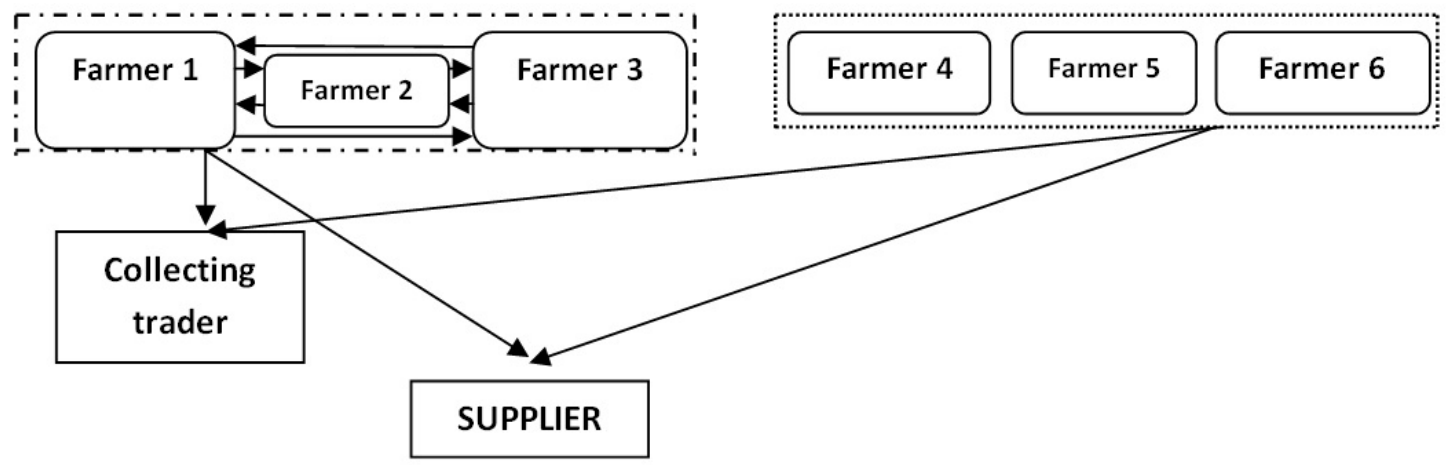

Figure 1 - Communication Network Pattern of Vegetables' farmer

The higher the education that the vegetable farmer has ever taken, the more knowledge about technology and science is expected to increase in terms of affective and cognitive. If the level of education pursued by vegetable farmers is high then the tendency to participate in communication networks is also high. The smaller the vegetable farming land the more integrated the farmers, because the smaller the land the intensity of land processing is more intensive. They will try their best to use existing land to get maximum results by more actively communicating with other farmers. The more experience the farmers the more open the farmers are to provide experience to other farmers and more open to get information. Characteristics of farmers have an influence on the communication network in the process of adoption of innovation.

The more farmers receive the exposure of information from the mass media the more likely they are to communicate and participate in the communication network. This is because the information they receive from the mass media they will talk about to get the same point of view. The greater the ownership of mass media means the greater the connectivity with other individuals, because the information obtained from the mass media will be discussed by fellow farmers.

The effect of farmers' participation in communication networks can increase farmers' knowledge of price, quality and purchase, but does not change farmers' actions in marketing. Farmers lack communications in terms of marketing because there are certain things that are not discussed with other farmers, especially in terms of sales. Competition to get a buyer or an opportunity for the product to be received by the collecting trader/supplier. As the main purpose of sales cause them less communicate with each other. Another cause is the weakness of farmers in bargaining position. They can only accept the price offered by the buyer and generally they are less active in finding new market shares.

In the case of informal institutional economy, informal institutions are not found that enter into the marketing system of highland vegetables in Buleleng Regency. To conduct the marketing of vegetables, some farmers establish good partnerships with collecting traders/suppliers. Partnerships between the two parties are relatively more institutionalized because they need each other. The rules governing the partnership mechanism are also formed based on their interests.In partnership relationship between farmer and collecting traders/supplier there is difference of range between small, medium/large, and big collectors. In small collecting traders, the scope of the partnership is within the immediate area of the 
hamlets, whereas in medium-sized collecting traders, the reach of partnerships with producer farmers can reach the nearest villages, and in large collectors, the reach of the partnership can reach the nearest sub-district. Collateral partnership with producer farmers is trust. Profits for partners/traders within this partnership network are continuity of supply. While the benefits for producer farmers is the guarantee of marketing and ease to get a loan both for household economic purposes and for the purposes of vegetable cultivation.

Vegetable marketing chosen by highland vegetable farmers in Buleleng Regency is an indirect marketing pattern or through a collecting traders, and there are few farmers who sell directly to retailers or end consumers. This is due to a lack of working capital and no access to markets. The required working capital includes the transportation cost from the farm location to the market that needs supply, market tax charges, loading and unloading of vegetables, rental stalls, and the costs of non-formal, such as the payment of security in the market. The inability of highland vegetable farmers to access markets that require supply due to lack of market information can be obtained. Sometimes the price of vegetables from producers (farmers) is much lower than the actual selling price. This is due to the overproduction or delay in delivering the product to the market.

The prices of some vegetable products always fluctuate outside the farmers' control. Fluctuations in vegetable prices are generally higher than fruits and crops. In other words, the imbalance between supply volume and consumer needs is more common in vegetables. Vegetable prices are very fluctuating with a very wide price range, especially after being linked with futures trading. At certain times, such as the harvest and rain season, the price of vegetables can be very low but at other times it can be very high. A very volatile price, theoretically will complicate business predictions, both profit and loss calculations and risk management.

Vegetable marketing margins are often very large, if the greater the marketing margin, the price received by producers will be smaller. This indicates that the marketing system becomes inefficient or does not occur market integration and the low rate of remuneration or part of the price received by the farmers. The cause of inefficient vegetable marketing is due to the low rate of return received by the farmer or the price part received by the farmer. In addition, the weak bargaining position is low due to over-supply which often occurs in vegetable harvest, resulting in low prices received by vegetable farmers in Buleleng Regency.

The essence of a communication network is a homofili relationship, that is, the tendency of farmers to establish relationships or social contacts with people who share the same attributes (farmers) or a little higher than their position (collecting trader). These conditions also happen between people who have unequal attributes (farmers - the main market /tourism market).

Communication is an important part of vegetable marketing. With communication, products that exist in an area can be delivered to other areasor with communication, producers (vegetable farmers) can relate to their customers.Communication also plays an important role in connecting between one farmer and another.In doing the farming there is an interaction between one farmer and another farmer.

As members of the community often involve the process of sharing information about an object between farmers who are invited to interact, among them is to share information about marketing as well as establish a communication network among vegetable farmers. Communication network is important to be developed in farming and marketing of vegetables, because it can provide information to farmers about the selling price, qualityand the shape of the product consumers want and the more profitable marketing goals.

To improve the bargaining position of farmers, cooperatives or farmer groups are expected to increase their role. Due to transportation cost factor is the consideration of majority of farmers in marketing their vegetable products, the cooperative / farmer group should improve the transportation service to transport the vegetable products produced. To improve the bargaining position of farmers also required the development of locally charged institutions. This effort can be initiated by identifying potential institutions in each village or region. 
RJOAS, 10(70), October 2017

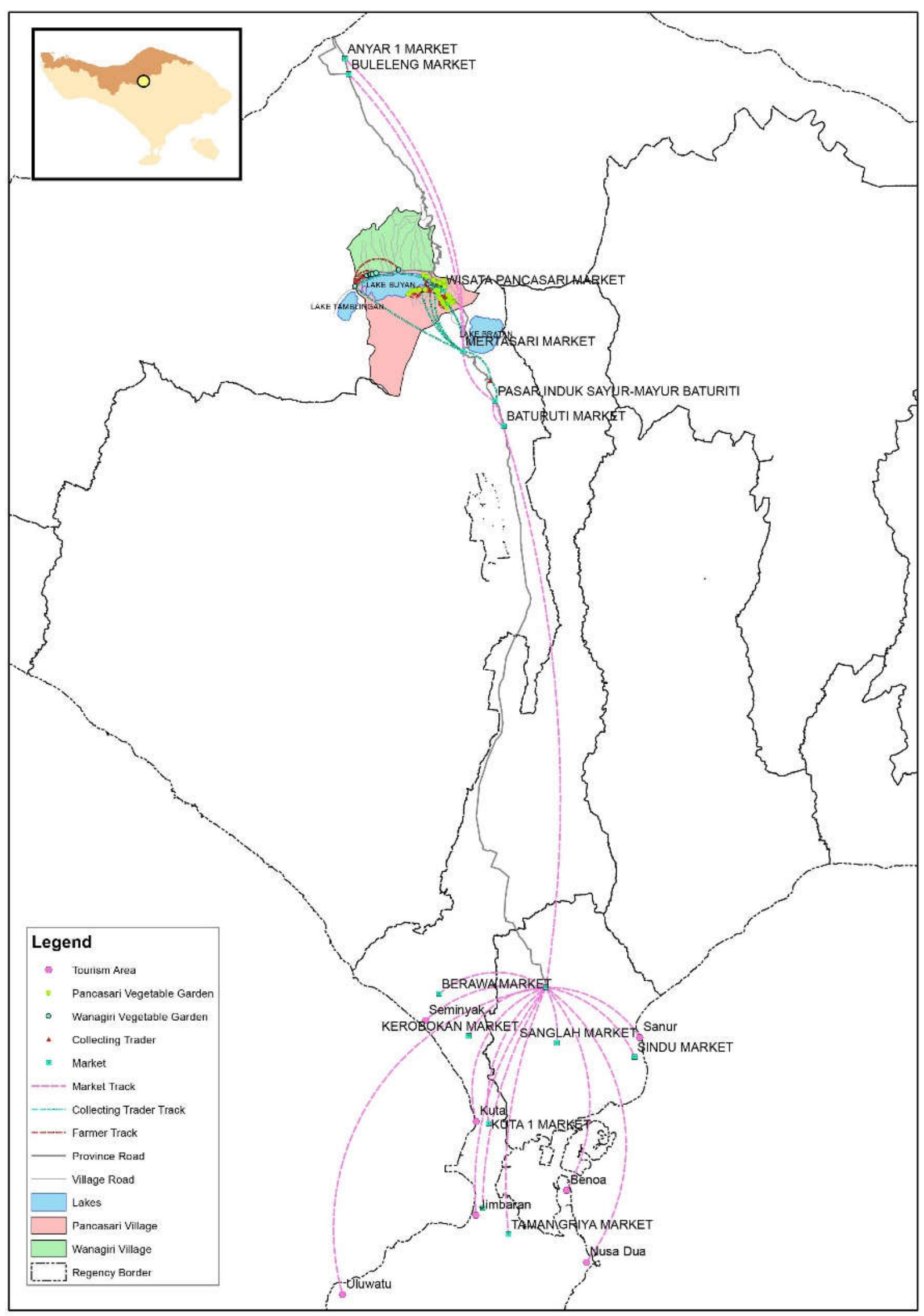

Figure 2 - Marketing of Highland Vegetables Production in Buleleng Regency 


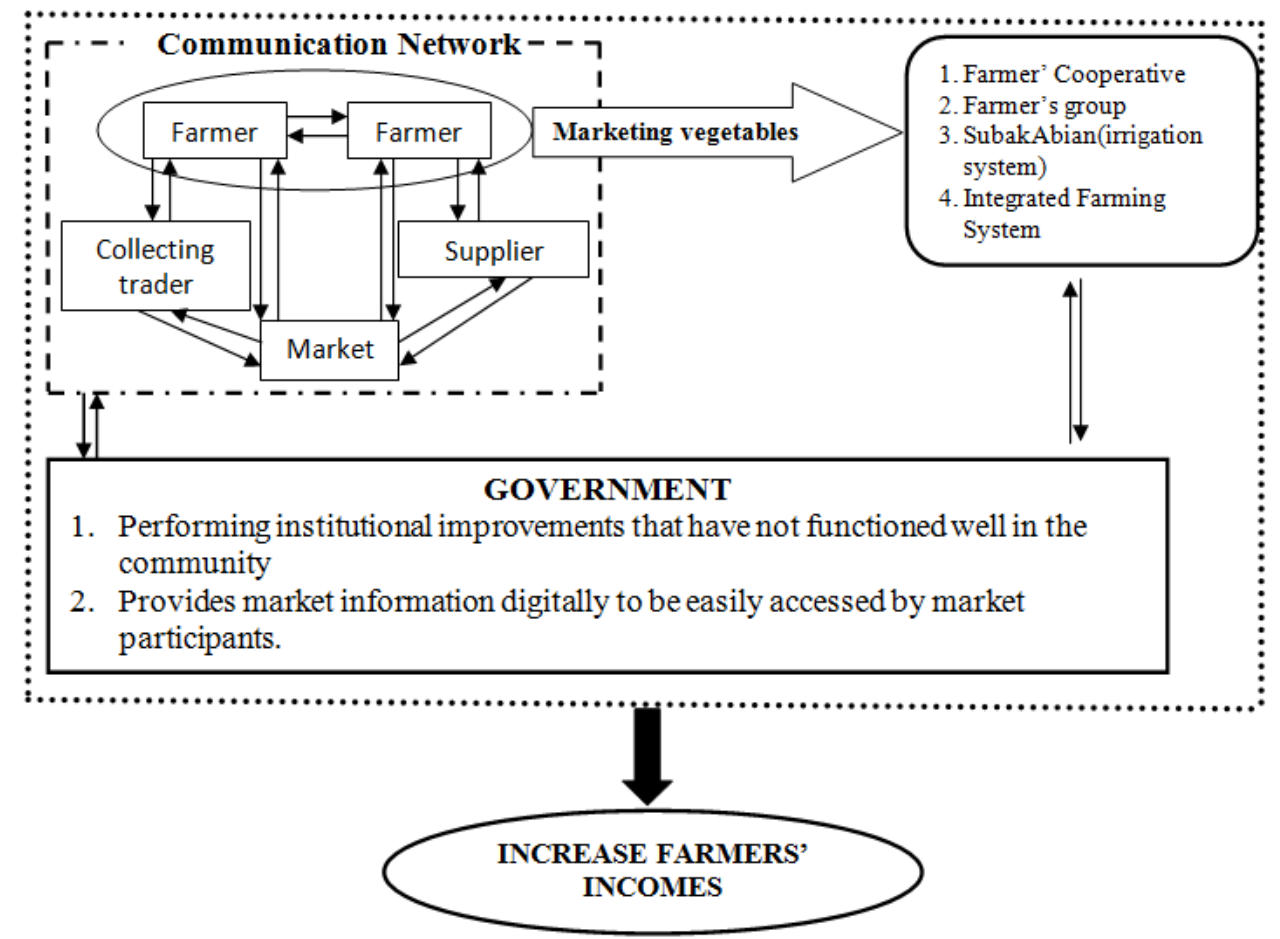

Figure 3 - Marketing Dynamics Model of Highland Vegetable Commodity

Based on the condition of marketing of highland vegetables in Buleleng Regency, there are two linkages that must be built in order to encourage the creation of vegetable commodity marketing system, including functional linkages or vertical hierarchical linkages between agribusiness actors, such as farmers, institutional and output traders. To encourage the creation of such functional linkages, the government does not have to make changes or introduce new institutional forms, but the government can make institutional improvements that are not functioning well in the community. This is because in general the institute has taken into account the issue of equity and business sustainability aspects for the parties that partner.

Governments should provide digital market information for easy access by farmers. Information about the market is a factor determining what kind of vegetables are produced, where, why, how and for whom vegetables are sold at their best. Therefore, appropriate vegetable market information can reduce business risk, thus traders can operate with low marketing margins and provide benefits for traders themselves, and farmers as producers.

Market information also includes marketing channels, with the objectives of producers and traders involved in the vegetable marketing channel and where the activity takes place can be known. In addition, the government should also digitally inform the applicable rules of the vegetable marketing channel system. Thus it is expected that the production of vegetables produced does not experience barriers in terms of network marketing expansion.

\section{CONCLUSION}

Sometimes the communications of one farmer with other farmers are not connected, this illustrates that the level of individuality of farmers in selling vegetables is still very high. Vegetable sales are also dominated by collecting trader or middleman. In a partnership relationship between farmers and collecting trader/suppliers there is a difference in the range between small collecting traders, medium collecting traders, and big collecting traders. In small wholesalers, the reach of partnerships within the areas of the nearest hamlets, whereas in medium-sized wholesalers of partnership with farmers can reach the nearest villages, while in large collecting traders the reach of the partnership can reach the nearest sub-district. 
The vegetable marketing margin is often very large, the bigger the marketing margin, the lower the price the producer receives. And indicate that inefficient marketing system or does not occur market unity. It also indicates low repayment or a price share received by farmers. To improve farmers bargaining position, farmers cooperatives or farmers group are expected to enhance their role. Due to transportation cost factor is the main problem consider by farmers to marketing their vegetable products, the cooperative/farmer group must improve the transportation service to deliver the products. Governments should provide digital market information for easy access by farmers. Information about the market is a factor determining what kind of vegetables are produced, where, why, how and for whom vegetables are sold at their best.

\section{REFERENCES}

1. Ansori, M. 2004. Jaringan Pemasaran Sayur-Mayur (Kasus Pemasaran Sayur-Mayur di Pasar Cibinong, Bogor). Makalah Individu Pengantar ke Falsafah Sains (PPS 702) Program Pascasarjana/S3, Institut Pertanian Bogor

2. Boyd, Walter, Larreche 2000. Manajemen Pemasaran Suatu Pendekatan Strategis dengan Orientasi Global. Jakarta. Erlangga.

3. Bulkis.2015. Analisis Jaringan Komunikasi Petani Tanaman Sayuran (Kasus Petani Sayuran Di Desa Egon, Kecamatan Waigette, Kabupaten Sikka, Provinsi Nusa Tenggara Timur).Jurnal Matematika, Saint, dan Teknologi. Volume 16. Nomor 2. September 2015. 28-42.

4. Ellyta. 2017. Jaringan Komunikasi Petani Dalam Pemasaran Lidah Buaya Di Kalimantan Barat. Jurnal ZIRAA'AH. Volume 42 Nomor 1. Pebruari 2017.30-39

5. Harmoko and Erik, D. 2016. Akses Informasi Pertanian Melalui Media Komunikasi Pada Kelompok Tani Di Kabupaten Sambas Dan Kota Singkawang. Jurnal Komunikator. Vol 9.No1.Mei 2016.1-10

6. Mubyarto. 1977. Pengantar Ekonomi Pertanian. Yogyakarta: Lembaga Penelitian pendidikan dan Penerangan Ekonomi dan social.

7. Permana, A. S., Bintoro, M. H. and Harris, N. 2006. Analisis Jaringan Pemasaran Komoditas Sayuran (Kasus Petani Kecil Ciwidey, Bandung). Jurnal MPI Vol. 1 No. 2. September 2006. 71-83.

8. Prahasta, E. 2014. Sistem Informasi Geografis: Konsep-konsep Dasar (Perspektif Geodesi dan Geoinformatika). Penerbit Informatika. Bandung. Pg.760.

9. Rahim. A and Diah Retno Dwi Hastuti. 2007. Ekonomika Pertanian. Penebar Swadaya. Depok.

10. Riasning, N.P. 2007. Efisiensi Pemasaran Sayuran di Kecamatan Baturiti Kabupaten Tabanan (Thesis). Magister of Agribusiness Study Program. Program Pascasarjana Universitas Udayana, Denpasar.

11. Tukan, C.J.M., Yulianti, Roshetko, J.M., and D. Darusman. Pemasaran Kayu dari Lahan Petani di Provinsi Lampung.

12. Santoso, T. A. 2014. Efisiensi Pemasaran Beberapa Komoditas Sayuran Utama di Kabupaten Indramayu. Jurnal Agri Wiralodra. Volume 6 No. 2-September 2014.9-18.

13. Soekartawi. 2004. Agribisnis Teori dan Aplikasinya. Raja Grafindo Persada. Jakarta.

14. Swastha, B. Sudkodjo. I, 2001. Pengantar Bisnis Modern. Liberty Offset. Yogyakarta Pascasarjana Universitas Udayana, Denpasar.

15. Utami, D. 2013. Jaringan Komunikasi Informasi Harga dan Pemasaran Sayur. Minor Thesis. Departemen Sains Komunikasi dan Pengembangan Masyarakat Fakultas Ekologi Manusia. Institut Pertanian Bogor.

16. Wedastra, M.S. 1999. Analisis Efisiensi Pemasaran Bawang Merah di Kabupaten Lombok Barat NTB (Thesis). Program Pascasarjana Universitas Brawijaya, Malang.

(c) 2017 by the authors. Licensee RJOAS, Orel, Russia. This article is an open access article distributed under the terms and conditions of the Creative Commons Attribution (CC BY) license: http://creativecommons.org/licenses/by/4.0/ 